\title{
DLACZEGO W HOLANDII TEMAT NARKOTYKÓW MIĘKKICH NIE JEST KONTROWERSYJNY? HISTORYCZNE I SPOLECZNE UWARUNKOWANIA HOLENDRÓW I ICH WPLYW NA KSZTAŁTOWANIE SIE PRAWA
}

\begin{abstract}
Streszczenie. Wyjątkowa sytuacja prawna Holandii odgrywa nieocenioną rolę w sporze o legalizację narkotyków miękkich. Jednak temat ten, mimo oryginalnych uregulowań, od dawna nie jest już kontrowersyjny. Wynika to z ciekawych uwarunkowań społeczeństwa holenderskiego oraz ważnych czynników historycznych. Artykuł przedstawia analizę tych specyficznych elementów wpływających na kształt regulacji odnoszących się do polityki narkotykowej. Ma on na celu ukazanie, jak istotne dla skuteczności prawa jest uwzględnienie takich uwarunkowań w procesie legislacyjnym.
\end{abstract}

Słowa kluczowe: miękkie narkotyki, polityka narkotykowa, legalizacja, Królestwo Niderlandów, uwarunkowania społeczne.

W sporze o legalizację narkotyków miękkich niezmiernie ważną rolę odgrywa sytuacja prawna w Holandii, czyli w kraju, w którym legalnie możemy zakupić marihuanę i haszysz oraz wyroby zawierające te środki odurzające. To również Holendrzy spopularyzowali pojęcie „narkotyków miękkich”, opierając swoją ustawę opiumową na podziale narkotyków na dwie grupy.

Niniejsza praca skupiać się będzie na analizie charakteru regulacji holenderskich, sposobie ich tworzenia, ale przede wszystkim na historycznych i społecznych uwarunkowaniach społeczeństwa, które miały wpływ na kształt holenderskiej polityki narkotykowej. Ma ona na celu ukazanie, jak istotne dla skuteczności prawa jest uwzględnienie tych czynników w procesie legislacyjnym.

Aktualne przepisy odnoszące się do polityki narkotykowej w Holandii bazują na podziale środków odurzających na „twarde” i „miękkie”. Podział ten został dokonany prawdopodobnie ze względu na stopień uzależniania danej substancji oraz poziom ryzyka dla zdrowia w przypadku jej zażywania, co wciąż budzi wiele kontrowersji ze względu na brak jednoznacznych i oficjalnych danych. Do grupy pierwszej (list I załączona do ustawy opiumowej) zalicza się środki, takie

* Uniwersytet Łódzki, Wydział Prawa i Administracji, Katedra Teorii i Filozofii Prawa, nazimekm@yahoo.com. 
jak: amfetamina, LSD, heroina i kokaina; natomiast do grupy drugiej (list II) produkty wytworzone z konopi siewnych, takie jak marihuana i haszysz. Należy podkreślić, że środki odurzające znajdujące się na obu listach są przez ustawodawcę uznane za nielegalne, to znaczy ich wytwarzanie, transportowanie, handel, posiadanie i używanie są tak samo przez prawo zabronione w przypadku substancji z listy „twardych”, jak i „miękkich” narkotyków (Krajewski 2001, 288). Różnica pojawia się dopiero w rozróżnieniu sankcji, ponieważ w przypadku substancji z listy pierwszej sankcje te są znacznie surowsze niż w przypadku substancji z listy drugiej.

Ważnym aspektem tych regulacji jest fakt, iż policja i prokuratura w Holandii posiadają dyskrecjonalną władzę w kwestii polityki narkotykowej (Silvis 1994, 44). Wynika to z naczelnej zasady, jako że organy ścigania mają kierować się przede wszystkim dobrem publicznym. Podstawą do takiego działania są specjalne wytyczne przygotowane przez prokuratorów wyższego szczebla, które nie są jednak zbiorem nakazów, lecz mają na celu jedynie wskazać priorytety, jakimi powinny kierować się policja i prokuratura. Wytyczne te nie są sztywne i podlegają interpretacji, co skutkuje przeniesieniem tworzenia polityki wobec narkotyków na poziom lokalny, gdzie zawierane są trójstronne porozumienia między organami samorządowymi, policją i prokuraturą (Krajewski 2001, 290). System holenderski opierając się na zasadzie oportunizmu, stworzył możliwość nieegzekwowania naruszanych norm zawartych w ustawie opiumowej. Zasada ta „wyznacza obszar rzeczywistego egzekwowania formalnego zakresu kryminalizacji” (tamże, 289). Oznacza to, że w praktyce zezwala na wiele więcej, niż można by wywnioskować bazując na aktach prawnych. Co więcej, według holenderskiego Sądu Najwyższego, jeśli w praktyce stosuje się wytyczne prokuratury w sposób spójny, zwięzły i konsekwentny, uzyskują one status norm obowiązujących, co oznacza, że w tym przypadku praktyka tworzy prawo (Silvis 1994, 48).

Według wytycznych priorytet ścigania przyznany jest produkcji, przemytowi i handlowi na wielką skalę (Krajewski 2001, 290). Oznacza to, że indywidualni konsumenci są całkowicie poza zainteresowaniem policji i prokuratury, które nie podejmują $\mathrm{w}$ tych przypadkach żadnych kroków, jakie na podstawie obowiązującego prawa podjąć by mogli. Co ciekawe, w praktyce oznacza to, iż mimo że posiadanie marihuany i haszyszu jest zabronione, funkcjonują specjalne sklepy, czyli coffee shops, w których istnieje możliwość legalnego zakupienia tego rodzaju narkotyków, pod warunkiem spełnienia określonych przesłanek. Specyficzna pod kątem uregulowań prawnych pozostaje również kwestia zaopatrywania coffee shops. Oficjalnie zarejestrowana kawiarnia nie może posiadać w lokalu więcej niż $500 \mathrm{~g}$, ale nieuregulowana została kwestia pochodzenia tego towaru, gdyż plantacje są w Holandii nielegalne, co z kolei prowadzi do istnienia swoistej „szarej strefy” (tamże, 296).

Oryginalny charakter holenderskiej polityki narkotykowej intuicyjnie prowadzi do rozważań nad sposobem tworzenia się regulacji prawnych dotyczących nar- 
kotyków miękkich. Mamy tu do czynienia z dwoma znanymi prawoznawstwu sposobami tworzenia prawa: przez jego stanowienie, a więc w tym przypadku mowa o ustawie opiumowej, jak również przez praktykę. W przypadku drugiego sposobu proces ten generalnie może przyjąć dwie formy: tworzenie prawa zwyczajowego lub tworzenie precedensu, charakterystyczne dla systemu common law. Prawo zwyczajowe powstaje poprzez ,podejmowanie decyzji przez organy państwa, na podstawie reguł zwyczajowych" (Wróblewski 1981, 36). Decyzja organu powiązana jest najczęściej z możliwością zastosowania środków przymusu w przypadku niezastosowania się do tejże decyzji, a więc uznać można takie sankcjonowanie zwyczaju za sposób tworzenia prawa zwyczajowego. Jest to prawo w rozumieniu połączenia reguł zwyczajowych z działalnością przymusowego aparatu państwa (tamże, 36). Decyzja, która jest podjęta na podstawie zwyczaju i która jest sankcjonowana, przekształca regułę zwyczajową w prawo obowiązujące.

Jako że Niderlandy to państwo systemu prawa stanowionego, tworzenie prawa poprzez stosowanie precedensów nie ma znaczenia dla problemu regulacji polityki narkotykowej. Natomiast można postawić pytanie, czy specyficzny status prokuratorskich wytycznych, które warto podkreślić jeszcze raz, nie sprawia, że mają one charakter prawa obowiązującego i podlegają pełnej interpretacji organów niższego szczebla, mieści się $\mathrm{w}$ ramach tworzenia prawa przez praktykę? Mamy tu do czynienia z odwrotną niż standardowa sytuacją, a mianowicie organy państwa odmawiają użycia środków przymusu, które przysługują im na podstawie prawa stanowionego, czyli ustawy opiumowej. Ta praktyka rezygnacji z karania czynów zabronionych wpływa bezpośrednio między innymi na depenalizację posiadania określonej ilości narkotyków miękkich, a co za tym idzie doprowadza do zmiany, chociaż nieoficjalnej, prawa obowiązującego w akcie zaliczanym do głównych źródeł prawa stanowionego, jakim jest ustawa. Zmiana prawa jest niczym innym, jak tworzeniem prawa nowego, co ostatecznie skłania do wniosków, że praktyka mająca miejsce w Holandii tworzy prawo obowiązujące. Do tego należy dołączyć umowy trójstronne zawierane na poziomie lokalnym, które regulują kwestie handlu detalicznego w oparciu o wytyczne prokuratury, co tylko utwierdza w przekonaniu o mocy obowiązującej tych wytycznych, jako że na ich podstawie, ze swobodą uznania i interpretacji, powstaje prawo stanowione lokalne. Efektem takiego systemu regulacji jest zróżnicowanie polityki narkotykowej na terenie kraju, najczęściej na zasadzie bardziej liberalnego podejścia w większych miastach, gdzie Amsterdam wysuwa się jako naczelny przykład, a także bazując na podziale kraju na konserwatywne, historycznie katolickie południe i liberalną, protestancką północ. Ważnym elementem tej formy tworzenia prawa mogą być również czynniki pozaprawne, takie jak opinia społeczna dotycząca danego problemu, tradycje odnoszące się do konkretnej kwestii w danym państwie, czy też uwarunkowania społeczne omawianej grupy.

Według rozpowszechnionych poglądów doktryny, prawo zwyczajowe posiada dwa elementy: zewnętrzny - czyli faktyczne przestrzeganie prawa i wewnętrz- 
ny - czyli przekonanie o zgodności zachowania z prawem. Na gruncie holenderskim można $\mathrm{z}$ łatwością odnaleźć te dwa czynniki w odniesieniu do polityki narkotykowej. W praktyce organy ścigania przestrzegają wytycznych prokuratorskich, co oznacza, że normy w nich zawarte są faktycznie stosowane przez organy państwowe. Dodatkowo panuje powszechne przekonanie wśród społeczeństwa holenderskiego, jak i w świadomości obywateli innych państw, że posiadanie określonej ilości narkotyków miękkich na terytorium Holandii jest dozwolone i wręcz zatrzymanie takiej osoby przez policję powszechnie uznane zostałoby za łamiące prawo. W tym przekonaniu umacnia również powszechna opinia o legalności narkotyków miękkich w Holandii, która, mimo że jest błędna, funkcjonuje na poziomie globalnym. Te fakty pokazują, jak bardzo głęboko zakorzeniona jest praktyka i jak ewoluowała ona w prawo zwyczajowe.

Uznać zatem należy, iż w procesie tworzenia polityki narkotykowej w Holandii ogromna rolę odegrały założenia realizmu prawniczego. Realizm, poprzez swoisty pragmatyzm, proponował, aby zastąpić dogmatyczne badanie aktów prawa stanowionego (law in books - ,prawo w książkach”, ,prawo oficjalne”), a skupić się na prawie w działaniu (law in action) (Oniszczuk 2008, 534). Przeciwstawiał się w ten sposób formalizmowi, który skupiał się na absolutnych wartościach w prawie, uznając, że nauka prawa powinna przedstawiać faktyczną praktykę prawną. Realiści uważali, że przepisy prawa nie powinny determinować decyzji sędziowskich, ponieważ norma prawna nie ma wpływu na to, czy stan w niej określony zostanie zrealizowany. Jako że związek przyczynowy zajść może tylko pomiędzy realnymi zdarzeniami społecznymi, nie istnieje on pomiędzy rzeczywistością społeczną a kategoriami normatywnymi (Zirk-Sadowski 2000, 229). Mimo że w Holandii system prawa nie należy do grupy common law i nie mamy w nim do czynienia z wyższością decyzji sędziowskiej nad prawem stanowionym, w praktyce holenderskiej ten podział prawa na in books i in action można zauważyć właśnie w kontekście podejścia władz do problemu narkotykowego, gdzie według prawa powszechnie obowiązującego, którego podstawą jest ustawa, środki odurzające wszelkiego rodzaju są nielegalne, a mimo to prawo w praktyce, „w działaniu" funkcjonuje w ograniczonym zakresie w sposób przeciwny. W tym przypadku, władza dyskrecjonalna została przyznana nie sędziemu, a organom ścigania, czyli policji i prokuraturze, a dodatkowo część uprawnień pozostaje w rękach władzy wykonawczej na poziomie lokalnym.

Realiści sprzeciwiali się koncepcji pozytywistycznej, zarzucając jej „nieuzasadnioną moc sprawczą tekstów prawnych", jak i prawnonaturalnej, krytykując ją za „poszukiwanie wzorców prawa przez spekulatywne rozważania, zastępujące badanie praktyki życia społecznego" (Chauvin, Stawecki, Winczorek 2009, 12). Oznacza to, że uznawali oni wyższość praktyki, jaka dominuje w danym społeczeństwie, nad normami prawnymi, które winny odzwierciedlać pewne wartości i skutkować osiągnięciem konkretnego celu, ale w rzeczywistości nie przynoszą zamierzonych efektów. Idea prawa skutecznego, odzwierciedlającego praktyki 
społeczne, widoczna jest w polityce holenderskiej poprzez odrzucenie całkowitej prohibicji, jako nieefektywnej, na rzecz częściowej quasi-legalizacji.

Biorąc pod uwagę wcześniej omówiony sposób tworzenia regulacji prawnych w Holandii, które kształtują politykę narkotykową oraz założenia realizmu prawniczego, które bezspornie leżą u podstaw całej koncepcji, warto zwrócić uwagę na bardzo skomplikowany charakter prawny holenderskich norm, na który wpływ mają wszystkie wyżej wymienione czynniki. Aby przedstawić ten problem, należy wyjaśnić terminy, z którymi często można spotkać się w dyskusji nad uregulowaniami prawnymi kwestii narkotyków, a które wciąż są mylnie rozumiane, szczególnie w środowisku laickim, co z kolei pociąga za sobą błędne określenie charakteru holenderskiej polityki narkotykowej, a mowa tu o pojęciu dekryminalizacji, depenalizacji oraz legalizacji. Według Encyklopedii Prawa pod redakcją U. Kaliny-Prasznic (Bojarski 2007, 113), dekryminalizacja to „zabieg ustawodawcy, w wyniku którego czyny uprzednio uznane za przestępstwa zostają pozbawione tej cechy, w wyniku czego nie są przedmiotem zainteresowania prawa karnego". Natomiast według tej samej Encyklopedii (tamże, 117), depenalizacja to „proces ustawodawczy, w wyniku którego czyn przestaje być zagrożony karą" i jest to „dalej idący zabieg niż dekryminalizacja”. Natomiast w Wielkiej Encyklopedii Prawa, pod redakcją B. Hołysta, pojęcie dekryminalizacji to „określenie często traktowane jako synonim depenalizacji. Niektórzy jednak różnicują te pojęcia, używając terminu dekryminalizacja dla oznaczenia pozbawienia czynu cech bycia przestępstwem przez ustawodawcę, a terminu depenalizacja albo dla oznaczenia całkowitej rezygnacji z zagrożenia czynu karą [...] albo dla oznaczenia złagodzenia przez ustawodawcę kary grożącej dotychczas za dany czyn" (Kunicka-Michalska 2005, 124). Natomiast pod hasłem depenalizacja rozumie się, że jest to „rezygnacja przez ustawodawcę z uznania czynu za czyn karalny, czyli za czyn zagrożony karą (tamże, 129).

Odnosząc się do tych definicji, przyjmiemy, że pojęcia te nie są synonimami, dekryminalizacja jest pojęciem o węższym zakresie, ponieważ pozbawia ona czyn jedynie cech przestępstwa, jednak dalej może on być wykroczeniem, natomiast depenalizacja usuwa zagrożenie karą (nie biorąc pod uwagę teorii o łagodzeniu kary, ponieważ pojęcie to wchodzi wówczas w zakres pojęcia dekryminalizacji), co powoduje, że czyn nie jest już ani przestępstwem, ani wykroczeniem. Do tych pojęć należy dodać również pojęcie legalizacji. Legalność to „cecha przypisywana zachowaniom lub aktom normatywnym, zawierająca się $\mathrm{w}$ stwierdzeniu, iż są one zgodne z prawem obowiązującym" (Zirk-Sadowski 2000, 400), a więc za legalizację czynu można uznać proces uznania go za zgodny z prawem.

W odniesieniu do holenderskiej polityki wobec narkotyków bardzo trudno jednoznacznie określić charakter prawny tamtejszych regulacji. Biorąc pod uwagę praktykę, do faktycznej dekryminalizacji doszło już w latach pięćdziesiątych minionego wieku, kiedy to nieoficjalnie pozwalano na detaliczny obrót marihuaną i haszyszem. Następnie zmiany kierunku polityki narkotykowej, wprowadzające 
oficjalny podział na narkotyki miękkie i twarde, w połączeniu z niewiążącymi wytycznymi prokuratury, pozwalały potwierdzić proces częściowej, bo mowa tu tylko o narkotykach z listy II, dekryminalizacji, a nawet depenalizacji, którą potwierdziły wytyczne prokuratury, niemające jednak charakteru prawa powszechnie obowiązującego i będące jedynie zbiorem postulatów kierowanym do organów ścigania. Pojęcia legalizacji natomiast można teoretycznie użyć dopiero wtedy, gdy na poziomie lokalnym została wydana zgoda na obrót detaliczny, a i wówczas wydaję się, że jest ono użyte nieco na wyrost, ponieważ bazując na obowiązującym prawie, a więc na ustawie opiumowej, akcie prawnym znajdującym się wyżej w hierarchii aktów normatywnych niż prawo lokalne według systematyzacji pionowej (Morawski 2011, 72), która wyraźnie wskazuje posiadanie, używanie oraz handel jako czyn zabroniony, użycie tego pojęcia traci na adekwatności. Jednak mając pełen obraz regulacji, a także wiedzę dotyczącą umów trójstronnych między władzami miast, prokuraturą i policją, wytycznych dla organów ścigania i powszechnych praktyk, można uznać to określenie za prawidłowe, jeżeli pamiętamy o specyfice takiego rozwiązania prawnego. W pewnym skrócie myślowym można używać pojęcia legalności narkotyków miękkich, jednak trzeba pamiętać, że w najdalej posuniętym stwierdzeniu jest to quasi-legalność, ze względu na ograniczenia ilościowe i rodzajowe. Używanie tego pojęcia bez szerszego wyjaśnienia może bardzo łatwo prowadzić do mylnego obrazu sytuacji prawnej w Holandii, a co za tym idzie wielu nieprawidłowych, a często i krzywdzących ocen tego systemu prawnego, jak i społeczeństwa holenderskiego. Bazując na tej specyfice, łatwo można odnieść się do podziału prawa na law in books i law in action obecnego $\mathrm{w}$ realizmie prawniczym, którego koncepcje są zauważalne w polityce holenderskiej.

Na kształt obecnych regulacji dotyczących narkotyków miękkich ogromny wpływ miały czynniki historyczne. Państwo holenderskie już w XIX wieku wyróżniało się na tle krajów Zachodniej Europy i Stanów Zjednoczonych specyfiką swojej polityki narkotykowej (Dolin 2015). Wbrew wszelkim pozorom nigdy nie był to kraj wolnych narkotyków, jednak kilka historycznie istotnych czynników wpłynęło na kształt regulacji prawnej tego problemu, co ma swoje odzwierciedlenie w aktualnym stanie prawnym. Aby zrozumieć historyczne uwarunkowania kwestii narkotykowej w Holandii, należy skupić się na trzech kwestiach: rozwoju medycyny w tamtym okresie, braku problemu uzależnionych żołnierzy holenderskich oraz wpływów z handlu narkotykami w koloniach niderlandzkich.

W XIX wieku społeczeństwo korzystało z dwóch typów medycyny: „prymitywnego-tradycyjnego" - gdzie opiaty, takie jak morfina, odgrywały znaczącą rolę, oraz „racjonalnego-naukowego” - który zbliżony był do współczesnych metod leczenia, obejmujących opiekę lekarską i hospitalizację (de Kort 1994, 4). Zła sytuacja ekonomiczna społeczeństwa holenderskiego spowodowała, że znacznie popularniejsze stały się ,prymitywne” sposoby leczenia, a co za tym idzie wszelkiego rodzaju opiaty stosowane były w przypadku wielu dolegliwości (tamże, 4). 
W późniejszych latach również kokaina i marihuana stały się powszechnie stosowanymi środkami medycznymi. W latach osiemdziesiątych XIX wieku pojawiły się pierwsze głosy negatywnie oceniające takie praktyki, zauważone zostały niebezpieczne skutki stosowania opiatów, w szczególności ich silnie uzależniające działanie. Pojawił się wówczas problem obecnego na szeroką skalę morfinizmu, czyli uzależnienia od zażywania morfiny. Chociaż w generalnym zarysie historia narkotyków w Holandii na tym etapie nie różni się znacznie od tej w krajach zachodnich, to zjawisko morfinizmu nie było tak widoczne $\mathrm{w}$ tym kraju w porównaniu do Niemiec, Francji czy Stanów Zjednoczonych. Problem ten dotykał najczęściej żołnierzy, którzy w szpitalach polowych otrzymywali zawyżone dawki morfiny, co prowadziło do szybkiego uzależnienia. W czasie gdy trwały wojna francusko-pruska (1870 r.) i wojna secesyjna (1861-1865), Holandia nie brała udziału w żadnym konflikcie zbrojnym, co poskutkowało zmniejszeniem zakresu problemu morfinizmu (tamże, 5) wśród Holendrów. To z kolei doprowadziło do mniej radykalnej oceny ówczesnej praktyki medycznej i łagodniejszego ograniczenia stosowania w niej opiatów.

Ogromny wpływ na stosunek rządu holenderskiego do problemu narkotykowego z historycznego punktu widzenia miały zyski, jakie przynosiła produkcja i handel opiatami oraz kokainą. Holendrzy stosowali system nazywany „opium leasing”, który polegał na dzierżawieniu prawa sprzedaży opium, transportowanego statkami głównie do Holenderskich Indii Wschodnich, temu podmiotowi, który zaoferował najwyższą cenę. Dochody ze stosowania takiego systemu szacuje się na około 200 milionów dolarów w latach 1834-1875, natomiast na przełomie XIX i XX wieku kwota ta przekroczyła 500 milionów dolarów. Niderlandy stały się wówczas największym producentem kokainy na świecie, co pokazuje, jak silny wpływ na politykę narkotykową Holandii miał czynnik ekonomiczny, jak i polityczny w związku z ówczesnymi koloniami. Ogromne wpływy do skarbu państwa, kontrola sprawowana nad terytoriami, gdzie ludność masowo zażywała narkotyki w celach rekreacyjnych, potrzeba umacniania pozycji państwa na arenie międzynarodowej w gorącym okresie poprzedzającym I wojnę światową - to wszystko doprowadziło do postrzegania przez Holendrów narkotyków jako produktu, towaru, niczym nieróżniącego się od przypraw czy tytoniu. Dodatkowo w latach dwudziestych XX wieku w społeczeństwie holenderskim przeważała opinia, że tak zwana „wojna narkotykowa” nie może być wygrana (tamże, 11). Kontrola nielegalnego handlu spotyka się ze zbyt wieloma trudnościami i pociąga za sobą nieproporcjonalne obciążenia finansowe. Już na początku globalnego sporu przejawia się w tej kwestii holenderski pragmatyzm, który w późniejszych latach doprowadzi do częściowej depenalizacji posiadania, konsumpcji, a nawet detalicznego handlu określonymi substancjami. Proponowane przez kraje zachodnie, a w szczególności Stany Zjednoczone, metody postępowania, nie budziły ani w rządzie, ani w społeczeństwie holenderskim wystarczającego zaufania do skuteczności w osiągnięciu zamierzonego celu. Oczywiście, można kwestionować, 
czy była to faktyczna motywacja stojąca za postępowaniem władz, biorąc pod uwagę kwestie ekonomiczne. Niemniej należy mieć na uwadze ten fakt, jako że mógł on być asumptem do przyzwolenia, jakie dało i daje do dziś społeczeństwo holenderskie w kwestii narkotyków.

Warto zauważyć, iż obok czynników historycznych, również uwarunkowania społeczno-geograficzne ukształtowały holenderską kulturę prawną, bezpośrednio wpływając na obowiązujące prawo, szczególnie w kwestiach współcześnie kontrowersyjnych. Holandia jest prawdopodobnie jedynym krajem europejskim, gdzie warunki klimatyczne i położenie geograficzne wpłynęły w taki sposób na kulturę i tożsamość społeczeństwa. Kraj, którego blisko czwarta część znajduję się poniżej poziomu morza, od zawsze musiał radzić sobie z żywiołem wody. „Bóg stworzył świat, ale Holandię stworzyli Holendrzy" (Polder i Polanie 2015), jak głosi znane powiedzenie. W zestawieniu $\mathrm{z}$ historią tego szesnastomilionowego państwa, pokazuje ono, w jaki sposób jego mieszkańcy wzięli „los we własne ręce”. Ta zwycięska walka z siłami natury możliwa była dzięki mentalności Holendrów, ich zdolnościom organizacyjnym i pomysłowości, ale utrzymanie terenów przed zalaniem stało się możliwe przede wszystkim dzięki temu, że całe społeczeństwo działało razem, dzięki tolerancji i umiejętności kompromisowego rozwiązywania wszelkich konfliktów.

Holandia ze względu na swoje położenie geograficzne już od V w. p.n.e. walczyła z wodą. Fryzowie budowali swoje domy na nasypach ziemnych, a wzdłuż rzek tworzono wały w ochronie przed powodziami (Korzewski 2005, 65). Od czasów starożytności do dnia dzisiejszego, biorąc pod uwagę, że największa w historii państwa powódź miała miejsce w 1953 roku, i mimo nowoczesnych i innowacyjnych zabezpieczeń kraj ten nigdy w pełni nie uwolni się od zagrożeń, jakie stwarza takie usytuowanie, całe życie Holendrów skupione było wokół tego żywiołu, co spowodowało, że stali się oni światową potęgą w dziedzinie gospodarki wodnej. Takie geograficzno-historyczne uwarunkowanie ma bezpośrednie przełożenie na kulturę społeczeństwa. Przede wszystkim Holendrzy musieli zaakceptować konieczność częściowej rezygnacji z prywatnych interesów na rzecz dobra ogółu i jego bezpieczeństwa (tamże, 69). W obliczu zagrożenia status i pozycja wszystkich osób jest zrównana, każdy ma tak samo ważną rolę i również od każdej pojedynczej osoby zależy zwycięstwo całej społeczności. Wspólnota stała się ważniejsza od jednostki i każde indywiduum musiało zaakceptować ten fakt, by przeżyć.

Ze swoistą „kulturą wodną” wiąże się wiele cech społeczeństwa, które z łatwością można odnaleźć u współczesnych Holendrów. Uiterwaaden, czyli „wodne pola" - pasma ziemi pomiędzy rzeką a wałami, tworzą w Holandii dodatkowe zabezpieczenie przed powodzią, pokazując logiczne i praktyczne podejście do problemu, a także zasadę Holendrów, że z wodą nie warto walczyć, lepiej z nią współpracować (tamże, 79), co z kolei odzwierciedla sposób rozwiązywania wielu współczesnych konfliktów za pomocą dyskusji i współpracy ze społeczeństwem, zamiast sposobu odgórnego narzucania decyzji suwerennej władzy. Dobra organizacja i ścisła współpraca, jaka była wymagana przy zarządzaniu wodą 
i budowie polderów, wymagała kooperacji na wysokim poziomie, a także zdolności społeczeństwa do wypracowywania kompromisów, niezależnie od wszelkiego rodzaju sporów, także ideologicznych, co doprowadziło do utworzenia polder-modelu, czyli holenderskiego modelu konsensusu (Zweiffel 2013, 200). Od zawsze najlepsze były rozwiązania wzbogacające społeczeństwo i zapewniające bezpieczeństwo, a holenderski pragmatyzm, wymuszony uwarunkowaniami, wykreował metody rozwiązywania problemów w sposób najbardziej efektywny redukujące zagrożenie.

Te wszystkie cechy z łatwością można przenieść na grunt kwestii narkotyków miękkich. Oryginalny niderlandzki koncept jest bez wątpienia połączeniem tak cenionego przez Holendrów kompromisu oraz próbą uniknięcia konfliktów w społeczeństwie, w celu zapewnienia bezpieczeństwa. Przejawia się tu również typowy dla tego społeczeństwa pragmatyzm i umiejętność odsunięcia kwestii moralnych i ideologicznych na rzecz poszukiwania obiektywnie sprawiedliwego i przede wszystkim skutecznego rozwiązania.

Aby w pełni zrozumieć proces tworzenia się współczesnej polityki narkotykowej w Holandii oraz wymiar wpływów społeczeństwa holenderskiego i jego mentalności, należy wyjaśnić zjawisko filaryzacji, które miało miejsce głównie w pierwszej połowie XX wieku. Filaryzacja (nid. verzuiling) oznacza „pionową segregację społeczeństwa holenderskiego wzdłuż istniejących podziałów ideologicznych. Grupy o różnych zapatrywaniach religijnych i światopoglądowych utworzyły równolegle instytucje społeczne i edukacyjne na zasadzie równouprawnienia. Filaryzacja zapewniała możliwość tworzenia własnego świata społecznego [...], który obejmował wszystkie aspekty życia grupowego" (tamże, 78). Jakob Pieter Kruijt, badacz zajmujący się tą problematyką, podkreślał, że podstawą istnienia filaru była określona filozofia życia. Definiował on filary jako „bloki społeczne, jednolite rasowo i etnicznie, bazujące na fundamencie ideologicznym" (tamże, 79). Wyodrębnić można cztery bloki społeczne: katolicki, protestancki, socjalistyczny i liberalny, jednak co do tego podziału, jak i liczby bloków, wśród badaczy społeczeństwa holenderskiego zdania są podzielone. Filaryzację można uznać za „specyficzny wariant konsensualizmu” (tamże, 81), albowiem zasadniczym celem było osiągnięcie, w istotnych dla funkcjonowania państwa kwestiach, swoistego kompromisu, przy zachowaniu równości wszystkich grup wobec prawa. Separatystyczny pluralizm ideologiczny, inaczej nazywany „dobrowolnym apartheidem", gdzie tylko elity polityczne utrzymywały minimalne kontakty między filarami w ramach nadrzędnej struktury politycznej (Korzewski 2005, 167), doprowadził do powszechnej tolerancji jako nieingerencji w interesy innej grupy społecznej. Każda z „kolumn” miała własne szkoły, uniwersytety, partie polityczne, związki zawodowe, organizacje pracodawców, spółdzielnie mieszkaniowe, a także banki czy własne gazety. Każdy aspekt życia codziennego był w swoisty sposób zorganizowany przez dany filar. Zjawisko to spotyka się dzisiaj z różnymi ocenami. J. Kruijt twierdził, że filaryzacja prowadziła do izolacji poszczególnych 
grup społecznych, z kolei S. Sturman uważał to zjawisko za ,porażkę klasy robotniczej i ruchu wyzwolenia kobiet" (Zweiffel 2013, 81). Natomiast A. Lijphart twierdził, że takowy podział pozwolił zaakceptować różnice w społeczeństwie i może stanowić znakomity model rozwiązywania problemów politycznych, gdzie społeczeństwo jest głęboko podzielone. Wskazał on kilka zasad, którymi kierowali się Holendrzy i dzięki którym system ten mógł funkcjonować i zapewnić skuteczną realizację interesów poszczególnych grup w obrębie swoich filarów (Korzewski 2005, 164). Przede wszystkim „menadżerskie” podejście do polityki, którą należy traktować jak biznes, w którym nie ma miejsca na doktrynalne dyskusje. Polityczny kompromis powinien być oparty na zasadzie „zgody na niezgodę", czyli na pragmatycznym podejściu do rzeczywistości, w której występują odmienne poglądy ideologiczne.

W odniesieniu do problematyki narkotykowej zjawisko filaryzacji pokazuje nam, jak wolność i tolerancja ideologiczna od dawna były na pierwszym miejscu w społeczeństwie holenderskim. Zaobserwować można rzadką, szczególnie współcześnie, próbę akceptacji odmiennych poglądów politycznych czy wierzeń, osiągnięcia kompromisu i pokojowego współegzystowania. Oczywiście system, jaki został zastosowany przez Holendrów, miał również swoje negatywne strony, które można nawet uznać za przekreślające to rozwiązanie, jak chociażby wspomniana wcześniej izolacja grup społecznych, ograniczanie swobód poszczególnych jednostek na rzecz wolności grup pojmowanych jako jednolita całość oraz wielość zakazów w kwestii mieszania się społeczeństwa między filarami. Filaryzacja uważana była również za pewnego rodzaju formę kontroli społecznej, jednak nie można zapomnieć, że pozwalała ona na równe traktowanie odmiennych kultur i ideologii, co dało podstawy dla późniejszej akceptacji i tolerancji wszelkiego rodzaju odmienności, tak ważnej przy charakterystyce polityki holenderskiej.

W latach 60. nastąpił w Holandii proces defilaryzacji, który okazał się przełomowy z perspektywy omawianego tematu. Wpływ na upadek systemu filarowego miało bardzo wiele czynników, takich jak podwyższenie poziomu życia społeczeństwa, potrojenie się liczby studentów, rozwój technologiczny i urbanizacja, rozwój masowej turystyki, czy też pojawienie się pirackich stacji radiowych i telewizyjnych (tamże, 93). Spowodowało to swoiste „rozmycie” granic między filarami, a dodatkowo Holendrzy, głównie młodsze pokolenie, zaczęli interesować się wartościami wyższymi niż dobra materialne. Pojawiły się różne formy nacisku społecznego, poprzez tzw. aktiegroeps, czyli „oddolne inicjatywy społeczne związane już nie na bazie wspólnej ideologii, lecz raczej wspólnych, często doraźnych interesów związanych przede wszystkim z działaniami na rzecz przełamania pasywności społeczeństwa holenderskiego [...] oraz zwiększenia jego wpływu na władzę". To wszystko poskutkowało protestami społecznymi, różnego rodzaju happeningami i prowokacjami, które najbardziej zauważalne były w dużych aglomeracjach, takich jak Amsterdam. Pojawiła się grupa młodych, wykształconych „rebeliantów”, którzy utworzyli ruch o nazwie „Provo”. Początkowo spotykali się 
oni w centrum miasta, prowokacyjnie paląc marihuanę i starając się zwrócić uwagę społeczeństwa na inne, niż dotychczas głoszone, wartości. Część członków tego ruchu w późniejszym okresie utworzyła partię polityczną i zdobyła miejsca w radzie miejskiej. Wszystkie te zjawiska, włączając działający już wówczas ruch hipisowski, spowodowały, że w społeczeństwie holenderskim zaczęto kłaść nacisk na ochronę wolności osobistej i tolerancję wobec odmiennego stylu życia i wartości (Leuw, Marshall 1994, 25). W tym samym czasie pojawiła się również normatywna akceptacja odnosząca się do innych kontrowersyjnych problemów, takich jak legalizacja aborcji i pornografii, głoszono nieograniczanie prostytucji, homoseksualizmu czy generalnie wolności seksualnej (tamże, 26). Zjawisko defilaryzacji powiązane z przyczynami jego powstania bezpośrednio wpłynęło również na sposób postrzegania narkotyków miękkich. Wraz ze wzrostem popularności alternatywnego stylu życia oraz naciskiem na szeroko rozumianą tolerancję, te środki odurzające stały się niczym innym jak odmoralizowanym elementem kultury młodej generacji. Fakt ten jest bardzo istotny dla prawidłowego zrozumienia holenderskiej koncepcji legalizacji narkotyków miękkich.

$\mathrm{Na}$ ten sam okres historii Holandii przypada również proces sekularyzacji państwa oraz tworzenia się społeczeństwa multikulturowego. Sekularyzacja, czyli zjawisko, „dzięki któremu sektory społeczeństwa i kultury wyzwalają się spod dominacji instytucji i symboli religijnych" (Zweiffel 2013, 97), wraz z pozostałymi przemianami społecznymi spowodowała rozpad filarów, co pociągnęło za sobą załamanie się dotychczasowego systemu partyjnego, który oparty był na powiązaniach religijnych. Kraj, który był najbardziej religijnym państwem w Europie (ponad osiemdziesiąt procent społeczeństwa przynależało do różnych Kościołów), stał się najbardziej zdechrystianizowanym narodem kontynentu (w latach 90. ponad połowa Holendrów nie deklarowała już przynależności do żadnego z Kościołów) (tamże, 98). To spowodowało, że wyborcy zaczęli głosować zgodnie ze swoimi przekonaniami ideologicznymi, a nie z doktryną Kościoła, co skutkowało poważnymi przemianami politycznymi.

Państwo holenderskie nigdy nie dążyło do asymilacji obcokrajowców, co w konsekwencji spowodowało utworzenie się społeczeństwa multikulturowego. Oznacza to „współistnienie wielu kultur w obrębie jednej społeczności”, gdzie za pośrednictwem instytucji państwowych buduje się społeczeństwo mozaikowe (tamże, 113). Masowe ruchy imigracyjne w drugiej połowie XX wieku spowodowały pojawienie się nowych grup etnicznych, szerzyła się idea demokracji liberalnej, a filozofia wspierała akceptację odmienności i tożsamości tych grup przez państwo. Charles Taylor uważał, że „niemożliwe jest utrzymanie tożsamości oraz szacunku dla siebie, bez uznania innych", a Will Kymlicka twierdził, że współczesne społeczeństwo cechować będzie się pluralizmem i głębokim zróżnicowaniem i należy uznać prawa jednostek do pozostania przy swojej kulturze (tamże, 114). Faktem jest również to, że polityka holenderska zakładała, iż pobyt imigrantów ma być jedynie tymczasowy i należy ułatwić im powrót do ojczyzny poprzez 
kładzenie nacisku na umacnianie ich związków z krajem pochodzenia. Akceptacja tych praw w Holandii oraz tolerancja dla odmiennych kultur i poglądów zaszła tak daleko, że pojawiły się głosy kwestionujące tę politykę, mające szczególnie na uwadze społeczności muzułmańskie, charakteryzujące się, z punktu widzenia cywilizacji zachodniej, dyskryminacją kobiet bądź mniejszości seksualnych, co w Holandii było absolutnie nie do zaakceptowania.

Wszystkie te społeczne i polityczne zmiany, jakie dokonały się w Holandii w drugiej połowie XX wieku, poprzez filaryzację i odwrót tego zjawiska, sekularyzację $\mathrm{i}$ tworzenie się społeczeństwa wielokulturowego, a także popularne ruchy młodych, czy szerzenie się wartości wolności osobistej i tolerancji, miały ogromny wpływ na dzisiejszą politykę Holandii. Posiadając pełen obraz tych zmian, możemy zrozumieć, skąd pochodzi oryginalny na skalę światową koncept dotyczący narkotyków. Jest on mocno zakorzeniony w kulturze Holandii, która zawsze unikała radykalizmów i dążyła do konsensusu. Kompromis był dla Holendrów drogą do egzystencji dużych grup społecznych na ziemiach poniżej poziomu morza, które musiały działać wspólnie przeciwko niesprzyjającym warunkom geograficznym, zagrażającym odebraniem im ich terenów. Inni badacze uważają, że takie podejście społeczeństwa wynika z faktu, że Holandia jest krajem o „kulturze kobiecej”, gdzie najwyższym celem jest dbałość o dobre relacje międzyludzkie i pomoc słabszym (tamże, 200). Ta teoria znajduje potwierdzenie w sposobie postrzegania problemu narkotykowego, w nacisku kładzionym na opiekę medyczną i w metodzie radzenia sobie $\mathrm{z}$ osobami uzależnionymi, którym oferuje się wiele form pomocy, nie traktując ich jako sprawców przestępstw kryminalnych. Odnosząc się do współczesnych regulacji przez pryzmat kultury i wartości Holendrów, które zostały wykazane poprzez charakterystykę zmian społecznych i stosunku do różnych zjawisk występujących w tym kraju, można śmiało stwierdzić, że normy prawne odzwierciedlają poglądy tego społeczeństwa, jednocześnie wywodząc się z niego, a nie będąc jedynie samodzielną decyzją suwerennej władzy, a także są wciąż przez to społeczeństwo akceptowane. Nie można zatem nie dojść do wniosku, że wszelkie te połączenia w efekcie nie wpływają na skuteczność regulacji prawnych w Holandii odnośnie do kwestii wciąż kontrowersyjnych w pozostałych częściach świata, a całkowicie neutralnych emocjonalnie w kraju niderlandzkim.

$\mathrm{Na}$ koniec należy również podkreślić, jaką kluczową rolę w społeczeństwie holenderskim ogrywa wartość tolerancji, co znajduje swoje odzwierciedlenie w podejściu do wszelakich problemów, zarówno etycznych, kulturalnych, jak i politycznych. „W XVI- i XVII-wiecznej Europie, kiedy tolerancja była raczej wyjątkiem niż regułą, w Niderlandach [...] zakorzeniła się bardziej i zakotwiczyła bezpieczniej niż gdziekolwiek indziej. [...] W większym niż inne kraje stopniu Holendrzy skłonni są stawiać czoła takim nowym problemom, jak narkotyki, aborcja, eutanazja, homoseksualizm [...] - w duchu ogólnie rozumianej tolerancji, przekonani, że idea ta winna być urzeczywistniana również w tych [...] 
obszarach i że inne, niezdecydowane jeszcze społeczeństwa, docenią po jakimś czasie takie podejście" (Kossman 1997-1998, za Korzewski 2005, 9). Holandia od wieków szczyci się „,cnotą tolerancji”, a współcześnie powszechnie uznawana jest za najbardziej liberalne i tolerancyjne państwo, które kładzie szczególny nacisk na wolność jednostek.

W odniesieniu do tolerancji w wydaniu holenderskim, jak również do kwestii kształtowania polityki w oparciu o tę ideę, należy wyjaśnić pojęcie gedoogbeleid, czyli pojęcie polityki tolerancji pragmatycznej (Korzewski 2005, 129). Termin beleid oznacza potrzebę reakcji prawa na zachodzące w społeczeństwie przemiany, gdzie należy zachować „złoty środek” między zbyt restrykcyjnymi oraz zbyt pobłażliwymi uregulowaniami prawnymi. Natomiast termin gedogen oznacza sytuację, w której przy założeniu spełnienia określonych warunków, niekoniecznie formalnych, wykroczenie przeciwko konkretnej normie prawnej nie będzie sankcjonowane, co Bert Gordijn nazwał właśnie tolerancją pragmatyczną (Gordijn 2001, 231). Oznacza to nic innego jak oficjalne uznanie danego zachowania za nielegalne, przy jednoczesnym akceptowaniu możliwości odstąpienia od przestrzegania danej normy w określonych okolicznościach. Ma to na celu wypracowanie kompromisu między przedstawicielami dwóch przeciwnych stanowisk w danej kwestii, co pozwala na zachowanie ładu i bezpieczeństwa w zróżnicowanym społeczeństwie (Korzewski 2005, 130). Jest to nic innego jak praktyka „przymykania oczu”, przejawiająca się w pobłażliwości wobec łamania przepisów, która kiedyś ograniczała się do kwestii religijnych, a dziś ma o wiele szersze zastosowanie.

Należy pamiętać, że tolerancja nie była przez Holendrów od początku traktowana jako pozytywna wartość sama w sobie, ale raczej jako „skutek pragmatycznej i w gruncie rzeczy nieformalnej polityki nieinterwencji, jako efektywnej strategii zarządzania konfliktem i zapewnienia porządku wewnętrznego" (tamże, 137), co tylko podkreśla swoiste ideologicznie neutralne podejście do sposobu rządzenia krajem. Tolerancja stanowi tu środek do pokojowej koegzystencji w społeczeństwie tak różnorodnym początkowo religijnie. Wszelkie poczynania władzy miały na celu umożliwienie obywatelom różnych wyznań wspólnej pracy, a następnie służyły pokojowej organizacji życia społeczeństwa odmiennego etnicznie, politycznie i kulturowo, tak aby zapewnić wolność jednostkom. Warto również podkreślić znaczenie gospodarcze takiej polityki, jako że tolerancja sprzyjała interesom handlowym, a wszelkie uprzedzenia odbijały się negatywnie na ekonomii państwa (tamże, 141).

Wyżej przedstawione uwarunkowania i cechy społeczeństwa składają się na specyficzną kulturę prawną Holandii. Mają one przemożny wpływ na kształt regulacji odnoszących się do polityki narkotykowej, jak i innych kwestii współcześnie kontrowersyjnych. Wszystko to pokazuje, iż władze Holandii uwzględniają czynniki socjologiczne w procesie tworzenia prawa, dzięki czemu może ono cieszyć się mianem skutecznego i respektowanego. 


\title{
BIBLIOGRAFIA
}

Chauvin, Tatiana, Tomasz Stawecki, Piotr Winczorek. 2009. Wstęp do prawoznawstwa. Warszawa: C.H. Beck.

Dolin, Benjamin. National Drug Policy: The Netherlands. http://www.parl.gc.ca/content/sen/committee/371/ille/library/dolin1-e.htm [dostęp 31.07. 2015].

Gordijn, Bert. 2001. "Regulating Moral Dissent in an Open Society: The Dutch Experience with Pragmatic Tolerance". The Journal of Medicine and Philosophy 3 (26).

Hołyst, Brunon (red.). 2005. Wielka Encyklopedia Prawa. Warszawa: Prawo i Praktyka Gospodarcza. Kalina-Prasznic, Urszula (red.). 2007. Encyklopedia Prawa. Warszawa: C.H. Beck.

Korzewski, Marcin. 2005. O tolerancji w społeczeństwie i prawie holenderskim. Kraków: NOMOS. Kossmann, Ernst Heinrich. 1997-1998. "Toleration and Tolerance in the Netherlands". Low Countries. Arts and Society in Flanders and the Netherland.

Kort de, Marcel. "A Short History of Drugs in the Netherland". W Between prohibition and legalization: The Dutch experiment in drug policy, eds. Ed Leuw, Ineke Haen Marshall. AmsterdamNew York: Kugler Publications.

Krajewski, Krzysztof. 2001. Sens i bezsens prohibicji. Kraków: Zakamycze.

Leuw, Ed, Ineke Haen Marshall (eds.). 1994. Between prohibition and legalization: The Dutch experiment in drug policy. Amsterdam-New York: Kugler Publications.

Morawski, Lech. 2011. Wstęp do prawoznawstwa. Toruń: Towarzystwo Naukowe Organizacji i Kierownictwa.

Oniszczuk, Jerzy. 2008. Filozofia i teoria prawa. Warszawa: C.H. Beck.

Polder i Polanie. http://www.wiatrak.nl/14734/polder-i-polanie [dostęp 31.07.2015].

Wróblewski, Jerzy. 1981. Zasady tworzenia prawa. Łódź: Wydawnictwo Naukowe.

Zirk-Sadowski, Marek. 2000. Wprowadzenie do filozofii prawa. Kraków: Zakamycze.

Zweiffel, Łukasz. 2013. Dynamika zmian społecznych w Holandii i ich odzwierciedlenie w systemie politycznym XX i XXI wieku. Katowice: Edycja - Książki Naukowe i Specjalistyczne.

\section{Magdalena Nazimek}

\section{WHY IN THE NETHERLANDS THE SUBJECT OF SOFT DRUGS IS NOT CONTROVERSIAL? HISTORICAL AND SOCIAL CONDITIONS OF THE DUTCH SOCIETY AND THEIR INFLUENCE ON LAW}

\begin{abstract}
The legal situation of the Netherlands plays an invaluable role in the dispute over the legalization of soft drugs. However, this issue, despite the original regulation, is no longer a controversial topic. This is due to the interesting conditions in the Dutch society and important historical factors. The article presents an analysis of the specific elements influencing the shape of the regulation of a drug policy. Its aim is to show how important for the law effectiveness is to include such conditions into a legislative process.
\end{abstract}

Keywords: soft drugs, drug policy, legalization, The Netherlands, social conditions. 